\title{
STATUS OF \\ WATER DISPOSAL WELL (FAWN CREEK GOVERNMENT NO. 1) \\ PROJECT RIO BIANCO \\ June 20, 1974
}

This report was prepared as an account of work sponsored by an agency of the United States Government. Neither the United States Government nor any agency thereof, nor any of their exployees, makes any warranty, express or implied, or assumes my legal liability or responsibility for the accuracy, completeness, or usefulness of any information, apparatus, product, or process disclosed, or represents that its use would not infringe privately owned rights. Reference berein to any specific commercial product, process, or service by trade name, trademark, manufacturer, or otherwise does not necessarily constitute or imply its endorsement, recommendation, or favoring by the United States Government or any agency thereof. The views and opinions of authors expressed herein do not necessarily state or reflect those of the United States Government or any agency thereof. 


\section{DISCLAIMER}

This report was prepared as an account of work sponsored by an agency of the United States Government. Neither the United States Government nor any agency Thereof, nor any of their employees, makes any warranty, express or implied, or assumes any legal liability or responsibility for the accuracy, completeness, or usefulness of any information, apparatus, product, or process disclosed, or represents that its use would not infringe privately owned rights. Reference herein to any specific commercial product, process, or service by trade name, trademark, manufacturer, or otherwise does not necessarily constitute or imply its endorsement, recommendation, or favoring by the United States Government or any agency thereof. The views and opinions of authors expressed herein do not necessarily state or reflect those of the United States Government or any agency thereof. 


\section{DISCLAIMER}

Portions of this document may be illegible in electronic image products. Images are produced from the best available original document. 
BACKGROUND. . . . . . . . . . . . . . . . . . . . 1

Water Disposal Plans . . . . . . . . . . . . . . . 1

Recompletion - Fawn Creek Well . . . . ..... 1

Subsurface Disposal Permit . . . . . . .... 3

Production and Water Disposal History . . . . . . . . 3

Sampling History of the Disposal Well . . . . . . . 4

BLOWDOWN TESTOFWELL ........... 6

Operational Plan $\ldots 6$

Well Leak Test and Operations . . . . . . . . . . . 6

Sampling and Analysis. . ............... 7

DISCUSSION AND CONCLUSIONS . . . . . . . . . 8

PROPOSED REMEDIAL ACTION . . . . . . . . . . . 9

Appendix A Operation Plan for Fawn Creek

Government No. 1 Leak. Test and

Blowdown Sampling . . . . . . . . . 11

Appendix B Conoco Interoffice Communication,

Moffatt to Mann, Subject: Fawn

Creek No. '1, April 15, 1974. . . . . . . . . 15

Appendix C Data Tables, Blowdown Sampling. . . . . . 25

Figure 1 AS-BUILT DOWNA OLE COMPLETION DETAIL.

$\because$ FAWN CREE X GOVERNMENT NO. 1 WELL . . 2

Table I EIC ON SITE GAS TRITIUM ANAI YSES . . . : :- 25

Table II EJC ON SITE LIQUIDS-TRITIUM ANALYSES. : - 26

Table III COMPARISON OF LLL AND NERC-LV

GAS TRITIUM ANALYSES ..... . . . 27

Table IV COMPARISCN OF LIL AND NERC-LV

LIRUIDS TRITIUM ANALYSES ...... 28 


\section{Status of Water Disposal Well (Fawn Creek Government No. $1 \mathrm{Well}$ ) Project Rio.Blanco}

\section{BACKGROUND}

The plass* for reentry drilling and production testing of the Project Rio Blanco emplacement well called for a ten-day production test at a flow rate of about 30 million standard cubic feet (MMSCF) of gas per day, or a total of 300 MMSCF of gas. It was recognized that, if the flow capacity were greater than expected, it might be necessary to flow as much as 800 MMSCF of gas. The production test facility included a separator, water and hydrocarbon storage tanks, a critical flow prover,. and a stack'from which the produced gas was burned.

\section{Water Disposal Plans}

It was predicted that about 6,500 barrels (BBL) of water and little or no hydrocarbons would be separated from the planned $\mathbf{3 0 0}$ MMSCF flare. The corresponding prediction for the maximum of $800 \mathrm{MMSCF}$ was that 24,000 B BL of water would be separated. The predicted concentration of tritium (a byproduct of the nuclear explosions) in the separated water was 50,000 picocuries per milliliter ( $\mathrm{pCl} / \mathrm{ml})$, or about 8 curies $(\mathrm{Ci})$ of tritium per 1,000 barrels of water,

Two methods of disposal of this tritiated water were available; 1)to reinject the water into the flare and release it to the biosphere, or 2) to inject-the water into a disposal well, returning it to the formation from whence it came and thus not releasing the additional tritium to the biosphere. From the standpoint of developing the technology of nuclear stimulation of gas reservoirs, the alternative of subsurface disposal was considered to be desirable if it were technically feasible and the appropriate disposal permit was obtainable.

\section{Recompletion - Fawin Creek Well}

A nearby gas well, Fawn Creek Covernment No. 1, was available for the purpose of disposal of the tritiated water provided it were properly completed, As a precautionary containment step, this well had been stemmed with cement prior to detonation of the nuclear explosives, During the period June to September 1973, the well was reentered, opened up and dually recompleted as a water disposal well and as a gas producing well. The gas producing capability was required to hold the oil and gas lease, It was also useful as a source of on-site energy for heating the water storage tanks during freezing weather. The essential details of the dorabole completion are shown in Figure 1. The

* "Project Rio Blanco Definition Plan, Reentry Related Tasks, Volume III", CER Geonuclear Corporation, Las Vegas, Nevada, January 24, 1973. 


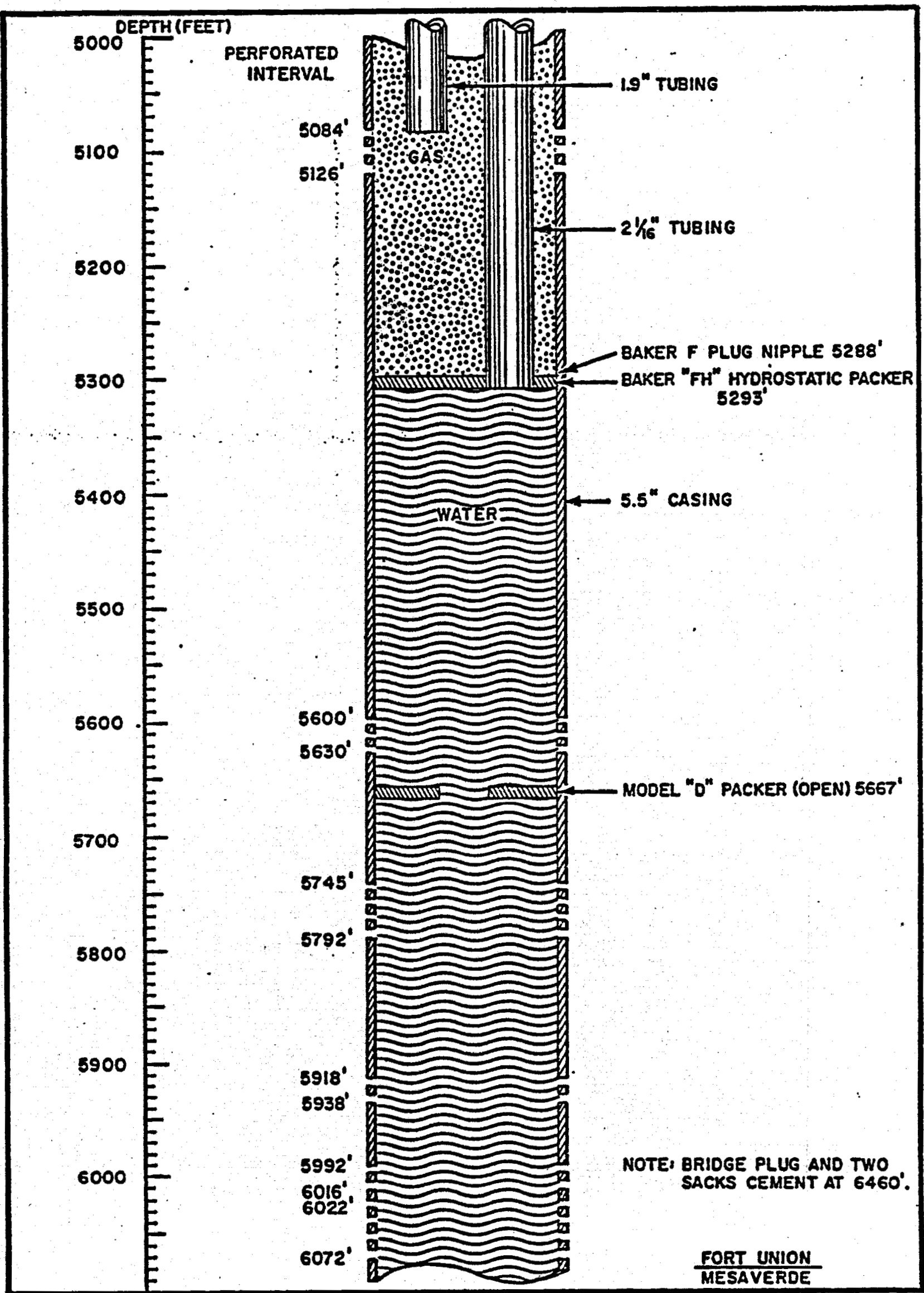

Figure 1. As-built dowahole completion detail, Fawn Creek Government No, 1 Well. 
Baker Model "FF" double grip hydrostatic packer used to separate the water injection zones from the gas producing zone was run into the well on 163 joints of the 2-1/16-inch tubing planned for use as the water injection string. Each joint of tubing was hydraulically tested for leaks after it was made up.' Two bad joints were found and rejected. The following statement is extracted from the drilling report+for September 14, 1973: "Packer landed at 5,293 ft KB. Falliburton circulated hole with 33 BBL, dropped ball and pumped down 2-1/16. inch with $12 \mathrm{BBL}$, pressured up and set packer. Ball sheared out of packer at 2,200 psig, Pumped down 2-1/16-inch at $1-1 / 2$ BBL per minute at 1,000 psig for 3 eninutes, no water returns to surface. Annulus went on vacuum while pumping down 2-1/16-inch tubing. " .

Subsurface Disposal Permit

The application to the State of Colorado by CER and Continental Oil to operate the subsurface disposal system described above resulted in the issu. ance'of a Persit for Subsurface Disposa! on November 9, 1973, by the Water Quality Control Division, Colorado Department of Health. The permit authorized the injection of not-more than 24,000 BBL of separated water into Fawn Creek Government No. 1 well over the interval of 5,600 ft to $6,072 \mathrm{ft}$ of depth. It further stipulated that the concentration of tritium shall not exceed 50,000 $\mathrm{O} \mathrm{i} / \mathrm{ml}$. (Bylater consultation with the Division, it was determined that this restriction should be interpreted to mean "average concentration of tritium. ..") The monitoring procedures for the disposal well contained in Exhibit $\mathbf{A}$ to the permit provided,. among other things, for "an analysis for tritium €or the gas and water produced from the disposal well (Fawn Creek Coverarout No. 1)".

\section{Production and Water Disposal History}

The first significant production test of the RB-I.01 well took place over the interval November 14-20, 1973. The well was shut in after the naridg of about 39 MMSCF of wet chimney gas; i. e., saturated with water vapor at the exit pressure and temperature conditions of the separator. The well ras shut in on Nobember 20, 1973, because the temperature of the produced gas was rising towards the temperature limitations of some of the equipment. 'During the period November 14-20, 1973, about 1,873 barrels of water were produced at the separator and stored in three $400.83 \mathrm{~L}$ holding tanks for analysis for radioactivity prior to disposal. Because of the high temperature of the separated water, it became necessary to dilute it with cool water from elsewhere to decrease the temperature below the boiling point of water $\left(200{ }^{\circ} F\right)$ at the ambient atmospheric pressure, 11.5 psia. In consequence, and partly because of the consumption of some water in pressure testing beforehand, a total of 3, 378 88L of water was injected into the disposal well over the period November 13-30, 1973. The average concentration of tritium in the injected

*"Daily Drilling Report - Fawa Creek No. I - Reentry, " E L. Moffatt, CER Geonuclear Corg, , Interoffice Memorandum, June 18, 1973 to September $17,1973$. 
water was 29,000 pci/ml, or a total of $15.54 \mathrm{Ci}$. From these data, it is calculated that the average concentration of tritium in the separated water prior to dilution was $\$ 2,000 \mathrm{pol} / \mathrm{ml}$.

The gas handling equipment was overhauled and modified to handle the high temperatures (up to 319 or) observed at the separator during the No- permber test. Three fin-fan coolers were installed in parallel ahead of the separator to permit operation of the separator in the temperature range of $100^{\circ} \mathrm{F}$ to $150^{\circ} \mathrm{F}$. The production testing was resumed on January 28, 1974 and continued until February 15, '1974, when the well was again shut in. A total of almost 63 MMSCF of wet chimney gas fas flared in this test, with the separation of 11,470 BBI of water and no hydrocarbon condensates. Although dilution water was not required to control the temperature, it was required to keep the cumulative average tritium concentration below the permit linitation of 50,000 pCl/ml. Accordingly, a total of 5,989 BBI of water was added to separated water prior to disposal. Of this amount, 533 BBL was used for system test and equipment decontamination, leaving $5,456 \mathrm{BBL}$ used for dilution. The injection of tritiated water extended from January 30, 1974 to February 26, 1974. A total of $134.40 \mathrm{Ci}$ of tritium as injected in this test, for a total of $149.94 \mathrm{Ci}$ in both tests. Of the $134.40 \mathrm{Ci}$ added, $133.12 \mathrm{Ci}$ were derived from the separated water, the remainder from equipment decontamination. It is calculated from these data that the average concentration of tritium in the injected diluted water was 49,000 $0 \mathrm{Cl} / \mathrm{ml}$, thile that for the separated water prior to dilution was $73,000 \mathrm{pCl} / \mathrm{ml}$. The cumulative average tritium concentration €or both disposal periods was $45,000 \mathrm{pCl} / \mathrm{ml}$, with a total injected water volume of $20,837 \mathrm{BB}$ L.

\section{Sampling History of the Disposal Well}

Pursuant to the provisions of the disposal permit, Eberline Instrument Corporation (EIC), who performed the on-site radiological safety functions under contract to CER, analyzed the gas produced.frors the disposal well on November 16, 17, 18, 20, 22, and 29, 1973. No tritium activity above the threshold for detection was found. The threshold for detection varies with the size of the aliquot assayed and is in the ragge or 23 to 10 picocuries of tritium per liter $(\mathrm{g} C \mathrm{i} / \mathrm{l})$ of gas at $\operatorname{STP}\left(0^{\circ} \mathrm{C}, 7 \mathrm{~T}^{0}\right.$ Hg). Fawn Cseek. separator liquids for assay were present onlv on November 16, 1973, and consisted entirely of hydrocarbons. A tritiun as say of this sample amounted to less than the minimuer detectable activity, $100 \mathrm{pCi} / \mathrm{ml}$ of liquid.

Additiona 1 analyses of the gas and assoclated liquids produced from the Fawn Creek disposal well frese made throughout the' pa riod January 25, 1974 to February 21, 1974, which covers the second production test and water disposal period, except for a final injection of 150 barrels of decontamination water on February 26, 1974. The technique for analysis of the gas consisted of burning it in an oxidizer with bottled oxygen, condensing the water of combustion and analyzing the water for tritium content with a liquid seintillation system. Normally, the gas was conditioned (liquids removed) with Drierite or Molysieve prior to burning. During most of this period the oxidizer was also being used to process samples of the emplacement well gas, whose tritium 
actipity was a factor of $10^{4}$ above the minimum detectable activity (i,e, three sigma of background) of about $3 \mathrm{pCi} / 1$ of gizs. Difficulty was eacourtered decontaminating the system to the minimum detectable activity between analyses of emplacement well gas and of Fawn Creek gas, To overcome this problem, an alternate oxidizer was brought on site in early February. This oxidizer, hereafter referred to as the EPA burner, uses ambient air to support combustion of a gas sample,

On January 25, 1974, positive low level tritium concentration was measured on Fawn Creek gas. This was initially attributed to cross-contarnina. Hoa from tritium calibration gases.used in the oxidizer. Further measurement on January 28, 1974 , confirmed the readings of about $7 \mathrm{pi} / 1$ of gas but repeated readings were erratic, Continuing measurements were made throughout the period, some using the original oxidizer but most using the EPA burner. The results ranged from not detectable to severaltens of $\mathrm{pCl} / \mathrm{ml}$ of combustion water, typically in the range of 5 to $20 \mathrm{pCl} / \mathrm{ml}$ of water, corresponding to the range of 8 to $32 \mathrm{p} / \mathrm{l} / 1$ of gas. Similar results were obtained on three samples of CP methane, burned in the $\Sigma F A$ burner on February 11, suggesting a hold-up of tritium in the burner or a contribution of tritium from site air moisture.

Samples of gas were taken directly from the Fasa Creek wellhead on January 29 and 30, 1974 and were divided for analysis annong EIC, the Lawrence Livermore Laboratory and the Environmental Protection Agency's National Eavironeatal Research Center at Las Vegas (NERC-LV). EIC processed its aliquot without drying the gas' and found tritium activity as high as $700 \mathrm{pl} / 1$ of gas, EIC also verified that the gas did not contain any ${ }^{85} \mathrm{Kr}$ activity above the minimum detectable level of $100 \mathrm{pCl} / 1$ of gas. ILL reported that:

1, The only measurable radionuclide in the'dry gas was ${ }^{222} \mathbf{R}$.

2. Tritium was not observed in the gas above the minimum detectable activity of $3 \mathrm{pCl} / 1$ of gas.

3. Tritium was not positively identified in the sample water, with a reported value (at three sigma of background) of $<50 \mathrm{pCl} / \mathrm{ml}$ of. water or $<1 \mathrm{pCi} / 1$ of gas.

$E P A-N E R C$ reported two results from its analyses of a January 30 aliquot. The first relates to the water of combustion of the unconditioned gas and shows tritium activity of $5.6 \mathrm{pCl} / \mathrm{ml}$ of water or $10 \mathrm{gCl} / \mathrm{l}$ of gas. The second, where the gas was dried prior to combustion, gave a background value of $<1.15 \mathrm{pCi} / \mathrm{ml}$ ofwater or $<0.24 \mathrm{pCi} / \mathrm{l}$ of gas, all at the 95 percent confidence level.

Additional samples of Fawn Creek gas were collected on February 15, 1974, and provided to LLL and NERC-LV for analysis. LLL reported that its analysis of this sample confirmed its prior conclusion that the tritium content of the Fawn Creek dry (conditioned) gas is not "statistically different 
from zero-, " but identified a low but measurable level of tritium activityin the liquids entrained in the gas; i. e., $7 \pm 1$ pCi/l of gas. The NERC-LV 'analysis of its aliquot of the February 15 sample confirmed the LLL result of no detectable tritium in the dry gas and found detectable tritium in the water extracted from the sample at a level of $95 \mathrm{pci} / \mathrm{l}$ of gas.

To put these values in perspective, it should be pointed out that the radioactivity concentration guide for tritium in water to which a suitable sample of the population is exposed, is $1000 \mathrm{pCi} / \mathrm{ml}$ of water. If this activity were measured in the combustion water of methane, the activity in the gas would have been about $1600 \mathrm{pCl} / \mathrm{l}$ of gas.

\section{BLOWDOWN'TEST OF WELL}

The data described above were considered inadequate to determine the source or magnitude of the observed tritium activity or to give insight into the mechasis for the occurrence of the activity. It ras apparent that the 1 roduced gas was carrying with it tritiated vapors of water or other compounds; c. F., the methanol being injected into the gas line to avoid freeze up. In $C O{ }^{-}$ si quence, the project participants developed plans to resolve these questions, if possible

Operational Plan

Attached as Appendix A is a copy of the detailed plans developed to test the water injection string for leaks and to produce the well at a sufficiently rapid rate to produce liquids and to obtain fresh gas from the formation. The principal elements of the plan were to:

1. Plug the water injection string-near the packer (Figure 1), pressure up the string with fresh water and record pressure over at least a 24-hour period to observe leak rate, if any.

2. Flow the well for at least $\mathbf{2 4}$ hours, sampling the gas on line with the EPA burner, and take periodic gas and liquid product samples for analysis by EIC on site and by LLL and NERC-LV in their lab. oratories.

Well Leak Test and Operations

Attached as Appendix B is a copy of the CONOCO Interoffice Communication dated April 15, 1974, which describes in detail the operations, including the leak test and the gas flow test.

The water injection string was flushed with fresh water and plugged near the packer (Figure 1). After plugging and pressurization with fresh water, the pressure time history at the surface was recorded from 1600, April 5, 1974, to 0800 on April 9, 1974, with a brief interruption on April 8 to change out a valve. After temperature equilibration, a small steady pressure drop

\footnotetext{
* Paragraph 4.5.5, Colorado Department of Health, Rules and Regulations Pertainingto Radiation Coatrol, 1970.
} 
was observed from 2300 April 5 until the conclision of the test. The pressure drop is attributed to the loss of about 1 gallon of water per day from the injection string.

The well was opened at 1020 April 9, 1974, and flowed to the mudpit until 1025 April 11, 1974, with estimated total production of 1.55 MMSCF of gas, $10 \mathrm{BBL}$ of water and $2 \mathrm{BBL}$. of condensate. The well was flowed from the gas productioh tubing except for the period from 1120 to 1315 on April 9 when it was flowed from the annulus..

Sampling and Analysis

Attached as Appendix $\boldsymbol{C}$ are detailed tabulations of the results of gas and liquids analyses performed on site by EIC and in their laboratories by LLL and NERC-LV.

EIC on-site analyses of 20 gas samples spread over the flow test period and processed for tritium assays were negative with minimum detectable activity of $4 \mathrm{pCi} / \mathbf{l}$ of gas, as listed in Table I of Appendix C. The gas analyses by LLL and NERC-LV are shown in Table II, Appendix $\boldsymbol{C}$. It will be noted that LLL obtained comparable negative results on three samples at a sensitivity similar to EIC's on-site sensitivity, Three other LLL samples and all seven of the NERC-LV samples were processed at greater senstivities. All tritium assays yielded results which were at or close to background values. The aximur ralue, reported by NERC-LV was '1.1 $+0.34 \mathrm{pCi} / 1$. of gas collected at 1110 on April 8, prior to the test, It should be pointed out that this value corresponds to a value of $0.7 \mathrm{pCi} / \mathrm{ml}$ of combustion water from methane, typical value for tritium concentration in surface waters.

The results of EIC on-site analyses of $15 \mathrm{w}$ ater and hydrocarbon samples collected throughout the fllow test period are shown in Table II, Appendix C. Sampling in the first few hours showed results in the range-of 2,200 to 2,800 $\mathrm{pCi} / \mathrm{ml}$ of recovered water. Thereafter, a steady decrease is apparent until the morning of April 10, when the values appeared to stabilize below 1000 $\mathrm{pCi} / \mathrm{ml}$, Fith the lor est value of $803 \mathrm{pCl} / \mathrm{ml}$ being reported for the sample collected just before shut-in of the well on April 11, 1974. Concurrent analyses on-site by EIC of four hydrocarbon samples were negative with a minimum detectable activity of about $80 \mathrm{pCl} / \mathrm{ml}$ of hydrocarbon.

The results obtained by LLL and NERC-LV in analysis of 15 sets of water and hydrocarbon samples collected throughout the flow test period are shown in Table $I V$, Appendix $\boldsymbol{C}$. The results obtained by both laboratories for water analyses agree closely with the EIC values, both as to magnitude and variation with time. With respect to hydrocarbon analyses, measurable levels were observed in some cases. LLL reported samples in the range of 5 to 7 times background, $24 \pm 5$ and $36 \pm 5 \mathrm{pCl} / \mathrm{ml}$, respectively. Six other LLL samples were not sigaificautly above background. NERC.LV reported all eight samples significantly above background, the first five, all collected on April 9, in the range of $21 \pm 0.39$.to $29 \pm 0.41 \mathrm{pl} / \mathrm{ml}$, and the last three, all collected after 1700 April 10, in the range of $5.4 \pm 0.26$ to 


\section{r}

$3.7 \pm 0.24 \mathrm{pl} / \mathrm{ml}$, decreasing with time. . LLL examined one sample, listed at $1 \overline{620}$ April 9, in detail. By a series of "washing" experiments, LLL determined that the observed activity was'not caused by dissolved tritiated water nor a material miscible with water. Some activity was carried over to methanol used to "wash" the sample, but actual identification of the tritiated compounds was not attempted.

Additional analyses of liquids associated with gas samples or recovered from molysfeve filters are shown in Tables II and 111, Appendix $\boldsymbol{C}$. Where they are correlatable with samples obtained, the results are seen to be generally consistent with the liquid sample results discussed above, with some unexplained variability. The preponderance of the sample evidence is that the levels of tritium in the gas, if real, would have no measurable effect on the environment.

\section{DISCUSSION AND CONCLUSIONS}

Tritiated water was introduced into the gas producing portion of the dually completed Fawn Creek Government No. $1 \mathrm{Well}$ at a rate of about $1 \mathrm{gallo0}$ per day. The leakage path has been suspected (Reference Appendix A) to be one of three possibilities:

1. mass flow through a small leak in the injection tubing above the packer,

2. Wass tom from the water injection zone below thepacker either through the formation or around the packer to the gas producing zone, or

3. atomic migration of stitiurn through the steel injection tubing into the liquids in the gas producing portion of the well.

That a leak of the right order of magnitude was found after plugging the tubing tends to support the thesis of a small leak in the injection tubing.

The order of magnitude of the leak cas be arsiyed at in a different way. To establish limits to the total volume of water and the total tritium leaked into the gas production portion of the well, consider three cases. Case 1 assumes that the water level was at $1600 \mathrm{ft}$ before the blowdown, (The well came on production on September 15, 1973, after being swabbed to a level of $1600 \mathrm{ft}$ ). Case 2 assumes that the level was at $4545 \mathrm{ft}$. This height corresponds to $10 \mathrm{BBL}$ of water above the perforations, at $0.0185 \mathrm{BBL} / \mathrm{ft}$. The real water level height is probably somewhere in between. Case 3 is taken to be with the water level at $4,000 \mathrm{ft}$. Using a value of $2500 \mathrm{pCl} / \mathrm{ml}$ of water as the average concentration of tritium in the well prior to the blowdown and dis regarding the volume of hydrocarbons, the following table summarizes the calculations arriving at leakage volumes. (Itwill be recalled that about $150 \mathrm{Ci}$ of tritium 
was injected, distributed through 20,000 BBL of water).

\begin{tabular}{|c|c|c|c|c|}
\hline CASE & & 12 & & $\underline{3}$ \\
\hline Assumed $\mathrm{H}_{2} \mathrm{O}$ level, & $\mathrm{ft}$ & 1,600 & 4,545 & 4,000 \\
\hline $\begin{array}{l}\text { Volume of } \mathrm{H}_{2} \mathrm{O} \\
\text { above packer }\end{array}$ & $\begin{array}{l}\mathrm{ft} 3 \\
\mathbf{m} \mathbf{I}\end{array}$ & $10.9^{384} \times 10^{6}$ & $2.2 \times \frac{78}{106}$ & $3.8 \times 10^{6}$ \\
\hline $\begin{array}{l}\text { Total }{ }^{3} \mathrm{H} \text { in well } \\
\text { above packer }\end{array}$ & $\mathrm{En}$ & 27 & 5.5 & 9.5 \\
\hline $\begin{array}{l}\text { Fraction of } \\
\text { injected }{ }^{3} \mathrm{H} \text { in well } \\
\text { above packer }\end{array}$ & & $1.8 \times 10^{-4}$ & $3.7 \times 10^{-5}$ & $6.3 \times 10^{-5}$ \\
\hline $\begin{array}{c}\mathrm{H}_{2} \mathrm{O} \text { leaked into well } \\
\text { above packer }\end{array}$ & BBL & 3.63 & 0.73 & 1.27 \\
\hline
\end{tabular}

Note that tritiated water was present in the iajection string from November 16-29, 1973 and from January 29 to February 20, 1973, a total of 35 days.

- Case 2 above corresponds to a leak rate of 0.9 gallons per day, while Case 1 corresponds to a leak rate of 1.5 gallons per day. These two results bracket the value of 1 gallon per day estimated from the pressure drop in the leak test prior to blowdown, Hence, Case 3 appears improbable.

The decline in tritium concentration during the blowdown test is attributed to producing back frac water from the formation which was not produced back when the well was flowed to the pit at 250 to $\mathbf{4 5 0}$ MCF per day on September 16, 17, 1973. The apparent levelling off of the tritium concentration would indicate that the dilution by production of frac water was decreasing or had essentially stopped.

The foregoing calculations assure no diffusion of ${ }^{3} \mathrm{H}$ into the formation. This assumption appears justified because of the very small area of the boundary (the perforations) across which diffusion would necessarily take place compared with the large surface area of the submerged casing. The 7alidity of the assumption is at least partly confirmed by the observed dilution in producing water from the formation.

PROPOSED REMEDIAL ACTION

In order to rehabilitate the Fawn Creek Government No. I well'as a gas producer and as a water disposal system, the following proposed program is submitted:

1. Kill the well by loading with water, 2 percent $K C$. 
2. Pull the plug from the injection tubing and displace the water below the packer with water; 2 percent $K C 1$.

3. Pull the 1.9-in. tubing.

4. Eull the 2-1/16-in; tubing and Baker "FH" hydrostatic packer.

5. Run Baker Model D́ packer on wireline and set at about 5,300 ft KB.

6, Run in 2-1116-in, tubing, hydrotesting each joint as it is made up.

7. Latch-2-1/16-in. tubing into Model D packer, run plug and pressure test eatize string for slight leaks. Retrieve plug.

8, Run 1.9-1a. gas production tubing and land as close to Model D packer as possible, estimated to be within 20 feet. Omit pin used previously:from bottom of string to permit use of foaming agent if necessary.

9. Swab well in through the 1.9-in. tubing, recovering residual water for analysis for tritium and later reinjection into water disposal zone, if necessary. (At an estimated tritium concentration of $1,000 \mathrm{p} \mathrm{Cl} / \mathrm{ml}$, the total tritium now in the $2-1 / 16-i n$. by $5-1 / 2-i \mathrm{a}$. annulus is in the neighborhood of several milileuries). 
Appendix A

Operation Plan for Fawn Creek Goverarse at

Well. No. 1 Leak Test and Blowdoriz Sampling

Apris 9,1974

\section{OBJECTIVE}

Analysis of previous Fawn Creek Well gas samples has provided data which indicate low level amounts of tritium are being detected. Analysis of samples from two separate laboratories (ILL and NERC-LV) and EIC field measurements have a wide range of values from 000 -detectable in the gas to as high as $7.4=10^{4}$ $\mathrm{pCl} / \mathrm{mI}$ in molysieve trapped distillates. Rather than pursue the reasons for the range of the. data a decision was made by CONOCO, CER and $A \Omega C / N V$ to attempt to determine the source of the tritium contamination. A plan had been propose-d, discussed, and agreed upon between CONOCO, CER, LIL, and AECTSV before the last production Iariag sbutin when field analysis had detected positive indications of tritium. The impetus of performing this test is reinforced by the. need to officlally report the mechanism of activity occurrence in writing to Colorado State authorities (a verbal report of the trace contamination has previously been made to Colorado State Health Deparne at officials).

Suspect sources are: A small leak in the contaminated water injection line into the upper gas suplying levels of the well; migration of tritium through the steel pipe in the gas supplying levels: and/or a formation leak from the LOFe : strata where the tritiated water is being lajected (through the packer or formation).

To investigate these possibilities the injection line will be flushed with clean water-and pressure checked, followed by a blowdown of the well to sample the formation gas, A series of samples will be taken during blowdown operation to determine if the well cleans up or continues to flow contaminated gas.

\section{PLAN}

A Work to be completed prior to April 9:

1. Displace the water in the injection tabing with frest rater (CONOCO).

2. Run tubing plug and land the plug as close as possible to the BAKRR. "EF" Hydrostatic Packer (CONOCO),

3. Pressure test overnight (i. e., 24 hours) to check for leaks at 1,500 1,800 psi (CONOCO),

4, Lay pipeline to nearby pit to blordown tubing and install madfold to blord annulus.' Both systems to bypass the separator (CONOCO). 
5. Install sample port in blooie Life for $\Xi I S$ to obtain liquid samples (a $1 / 2^{\prime \prime}$ female fitting to be installed at lowest point on line) (CONOCO).

6. Install sample port (1" female fitting) for taking gas'samples and EPA-Burne 5 hook-up on tubing head upstream from choke or control valve (CONOCO).

7. Install sampling manifolds and necessary sampling linea for liquid and gas sampling and install EPA-Burner. See lisyout sketch attached (E:C).

8. Check operation and calibrate Tri-carb and Oxidizer on RB location (EIC).

9. Run CP Methane through EPA-Burner and Oxidizer to cleanup system and verify baseline zero readings (EIC).

10. Seven gas sample bottles .ta be furnished by NERC-LV. Seven gas sarple battles to be furnished by II工L.

11. Water sample containers to be furnished by $\boldsymbol{\Sigma I C}$.

B. Beglaning April 9 ;

1. Blowdow tubing to approximately 200951 and blowdown annulus to obtain fresh gas in annulus (CONOCO). .

2. Concurrent Sampling (EIC):

a Continuous burn on EPA-Burner taking samples $(50 \mathrm{ml})$ as follows:

\section{(1) Prior to blowdown}

(2) Initial flow

(3) Every 4 hours thereafter except during nonattended night hours (schedule to be formalized by CIR/AIC).

b. SERC-IY and LIL gas bottle grab's aroples (coordinated with EPA.Burner samples) as follows:

\section{(1) Initial now}

(2) Every 8 hours from initial sample except gonattended night hours. When the annulus blowdown commences the closest scheduled 8-hour sample will be rescheduled to obtain a sample of the stale gas being flushed out of the annulus. 
hours thereafter). Should be prepared to take liquid sample at end of blooie line, if required.

. 3. Flow the well for at least 24.bours.; If field analysis of liquid/gas samples show-that tritium is not present at the end of $\mathbf{2 4}$ hours shut-in the well. If tritium is present at the end of $\mathbf{2 4}$ hours then coatinue well flow for second 24-hour period. (Gas bottle sarngling schedule in B. 2. above provides for 4 our sampling.)

C. Post Blowdow

1. Soip samples to $N E R G=I Y$, Las Vegas; and IIU, Liverm8re:

2. Demobilize and store equipment as necessary.

3. Provide copy of all raw data obtained to CER, CONOCO, LIL, and AEC/NV.

4. Schedule meeting at NV/HQ to resolve data and formulate notification to Colorado State.

cc:: PAD/NV

CER

CONOCO

LIL

EIC 

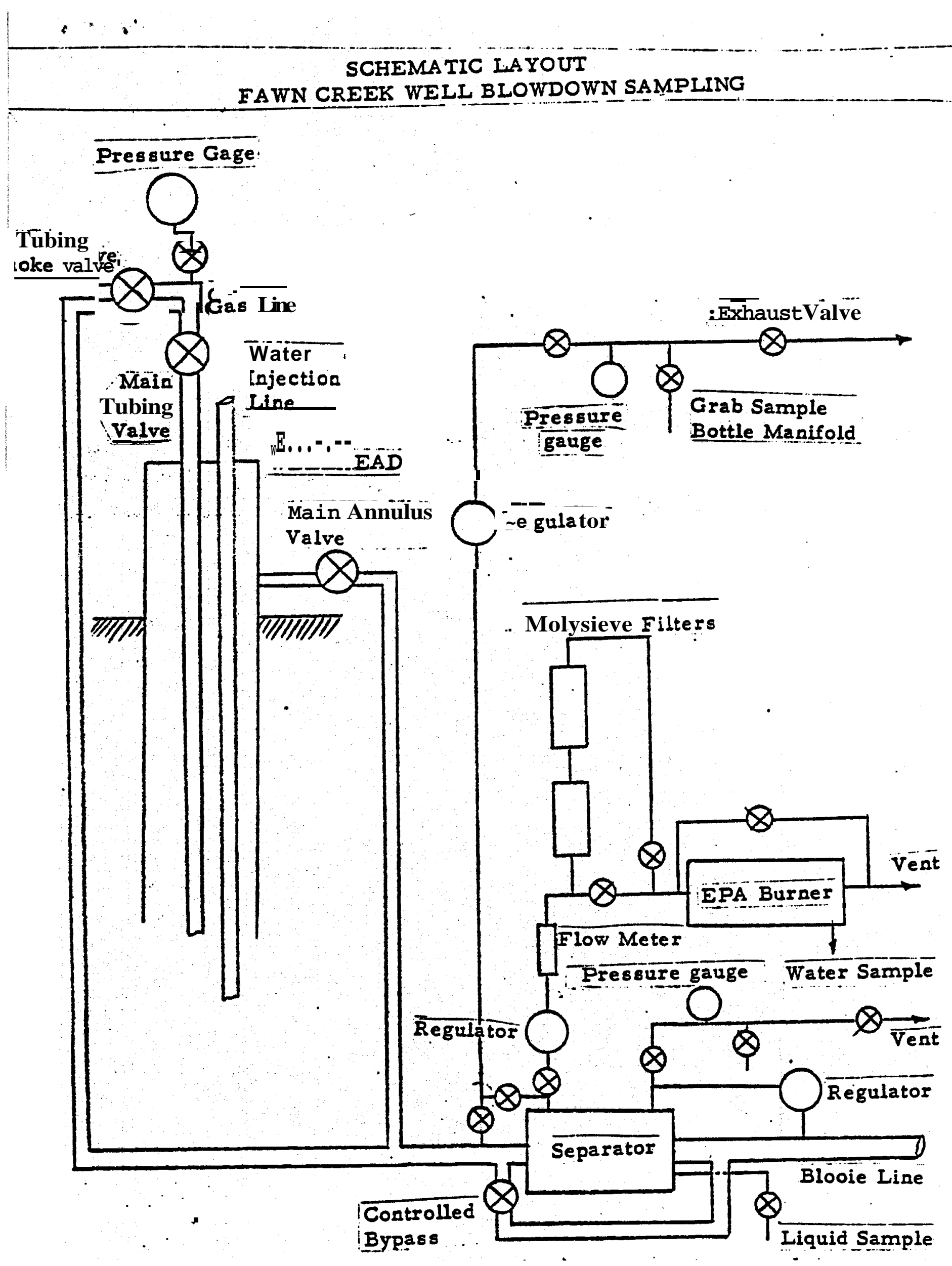


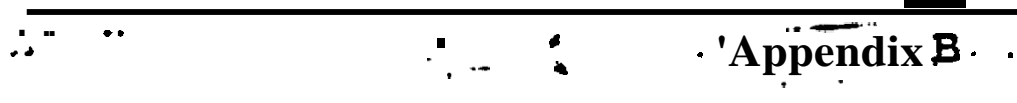

conoco

\section{Interoffice Communication}

To $\quad \mathrm{R}$ L. Mann

From E L. Moffatt

Date April 15, 1974

subjeet Fawn Creek \#1

Following is a reoort of operations on the subject well on a dally basis for the water injection tubing pressure test and the subsequent gas flow test. Daily reports are - status at 0800 hours on date indicated and indicates work done in previous 24 hours.

4 5/74 - Pumped fresh water from RB-0-01 well to water storage tank \#1 Checked out operation of Triplex pump. Orained fresh water Tine.,

4/6/74 : Opened water injection tubing valve on well head - found pressure at surface of $360 \mathrm{psig}$. 'Injected 30 bbl of fresh water down $21 / 16$ " tubing. Final injection pressure $1250 \mathrm{psig}$. Shut in tubing. Lubricated in Baker "FWG" blanking plug and wat 30 minutes for plug to reach plug nipple. Pressured tubing to 2425 psig with 2 bbl of fresh water at 1100 hours on 4/5/74. Shut in master valve-disconnected injection line at well head and bull plugged line access on well head. Opened master valve. Kept bleeding off inereasing pressure at well head for approximately 5 hours - (cold water expanding as temperature increased). At 1600 hours bled pressure to $2000 \mathrm{psig}$. Pressure increased to $2100 \mathrm{psig}$ at 2300 hours on 4/5/74 and then gradually decreased to 2085 at 0800 hours on 4/6/74.

4/7/74 - Shut down Fawn Creek \#1 gas flow to flare stack pilots - started on piping revisions at well head and at separator. Well head pressure on W.I. tubing decreased from 2085 osig at 0800 hours on 4/6/74 to 2065 psig at 0800 hours on $4 / 7 / 74$.

4/8/74 - Finished revisions to well head and separator for gas flow test. Pressure at well head on W.I. tubing decreased from 2065 psig at 0800 hours on $4 / 7 / 74$ to 2045 psig at 0800 hours on $4 / 8 / 74$.

4/9/74 - Pressure decifned from 2045 psig at 0800 hours on 4/8/74 to 2040 psig at 1420 hours on $4 / 8 / 74$, At that time a line to a recorder was disconnected and ${ }^{a} 1 / 2^{n}$ valve changed out. Approximately one quart of water was lost in this operation. When the pressure was monitored afte- thchange at 1425 hours the pressure was 2005 psig. ?he. pressure declined to 1980 psig at 0800 hours on $4 / 9 / 74$. The recorder was disconnected and placed on the $1.90^{4}$ tubing string for use during the gas flow test. 
R. I Mann

Page 2 15, 1974

4/10/74 - Status at 0800 - flowing well at $\sim 600 \mathrm{MCF} / 0$. Well is making $\sim 3$ BWPD and 1 BCPD, FTP 225 psig, CP 375 psig. Prior to openin gas flow

- the initial recorded tubing pressure was $1300 \mathrm{psig}$. The casing pressure was 1345 psig. The well was opened at 1020 hours on 4/9/74 to the separator from the tubing at a flow rate of $\sim 1.5$ MMCF/D. At 1120 hours the flow was switched to the 'casing and the flow rate was maintained at -1.5 MCF/O until 1235 hours then a separator by-pass valve was opened to blow the well down, The rate was increased to - 4.0 MMCF/O until 1315 hours. The flowing casing pressure was at $400 \mathrm{psig}$ and the tubing pressure was at 500 psig. Flow was switched from the casing to the tubing at 1315 hours, and the gas by-pass around the 'separator was closed. The tubing pressure dectined to 150 psig a t 1330 hours and then the well started making liquid to the separator. Slugs of liquid were produced until 1415 hours. Approximately 5 bbl of water and $1 \mathrm{bbl}$ of condensate were produced. during this interyal. After the liquid slug was produced the tubing flowing pressure increased to $\sim 400 \mathrm{psig}$ and the casing pressure increased to $\sim 600 \mathrm{psig}$. Flow rate was at $\mathbf{7 5 0}$ $M C F / D$. Liquid production was at $\sim 3$ BWPD and 1 BCPO. AEC and EIC personnel took liquid and gas samples during the flow period. EIC field analysis indicates $\sim 1000 \mathrm{p} / \mathrm{C} / \mathrm{ml}$ of radiation or florescence in the water, None has been detected in the gas or in the liquid hydrocarbon. The CER Trykry has not detected tritium in the gas.

4/11/74 - Status at 0800 hours - flawing well at $\sim 550$ MCF/D. Well is making - 2VPD and 1/2 8CPD. FTP $170 \mathrm{psig,} \mathrm{CP} 300$ psig. EIC and AEC personnel took gas and liquid samples during the flow period. Radiation or florescence in the produced water is $\sim 1000^{\circ} \mathrm{p} / \mathrm{C} / \mathrm{ml}$. No tritium has been detected in the gas.

4/12/74 - Well shut in. Flowed well until 1025 hours 4/11/74 - Final pressures were FTP $165 \mathrm{psig}$, CP $305 \mathrm{ps} / \mathrm{g}$, Gas flow rate $~ 550 \mathrm{MCF} / \mathrm{D}$, liquid production rate $\sim 2$ BWPD and $1 / 2$ BCPD. EIC and AEC personnel took final samples of liquids and gas at 1020 hours on 4/11/74. Following are estimates of fluids flowed from the well during this test:

Cum. produced gas

Cum. produced water

cum. produced condensate $1550 \mathrm{MCF}$.

10 bb

2 bbl

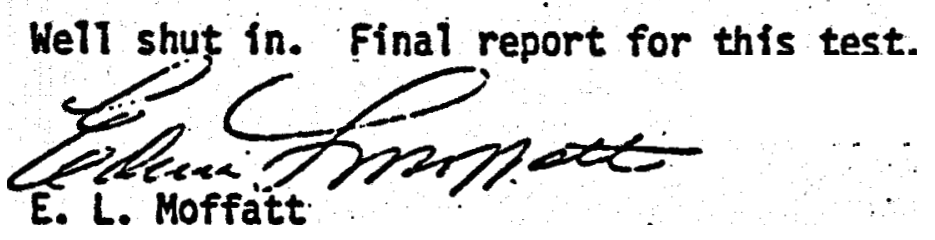

ri 


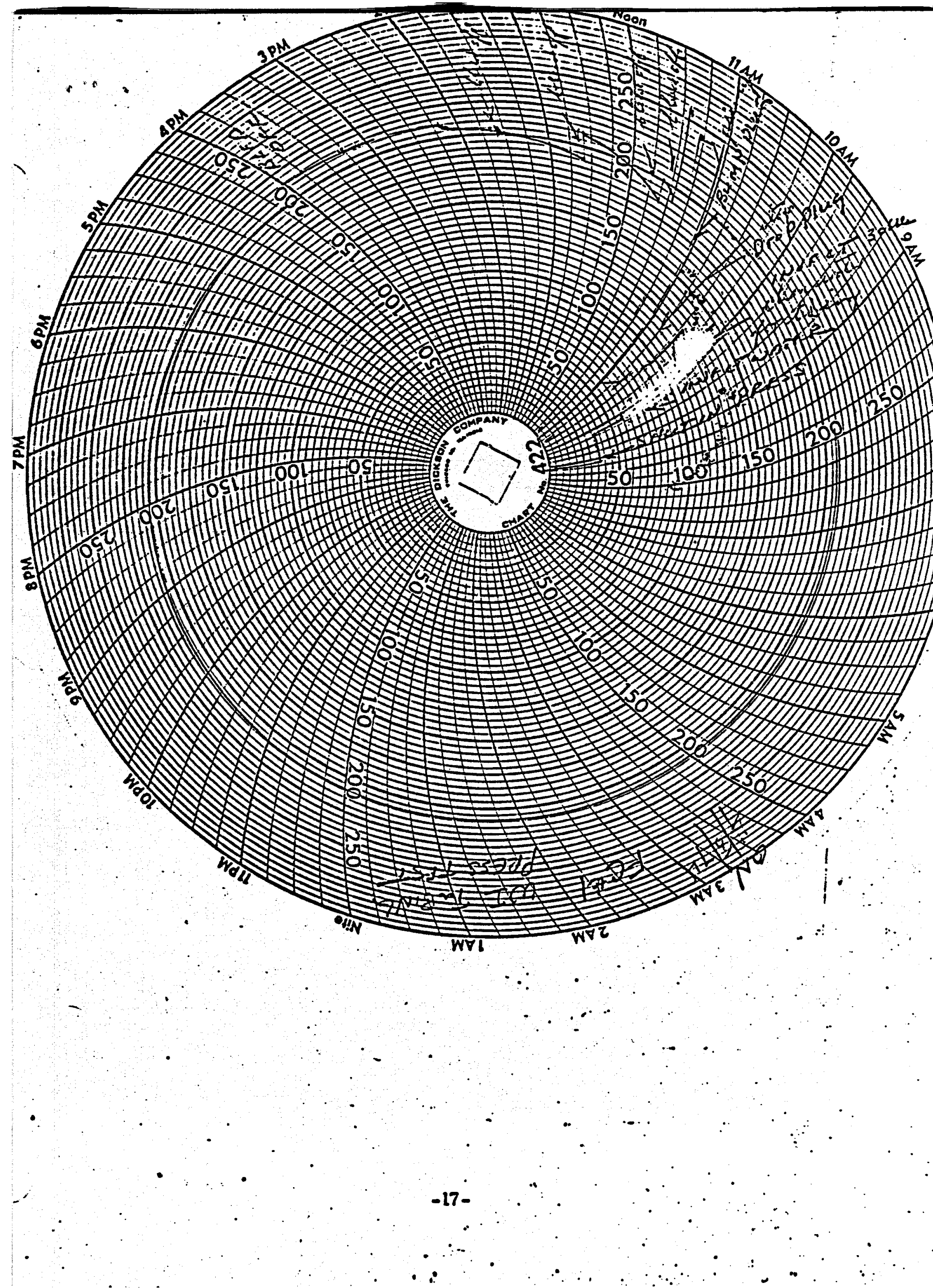









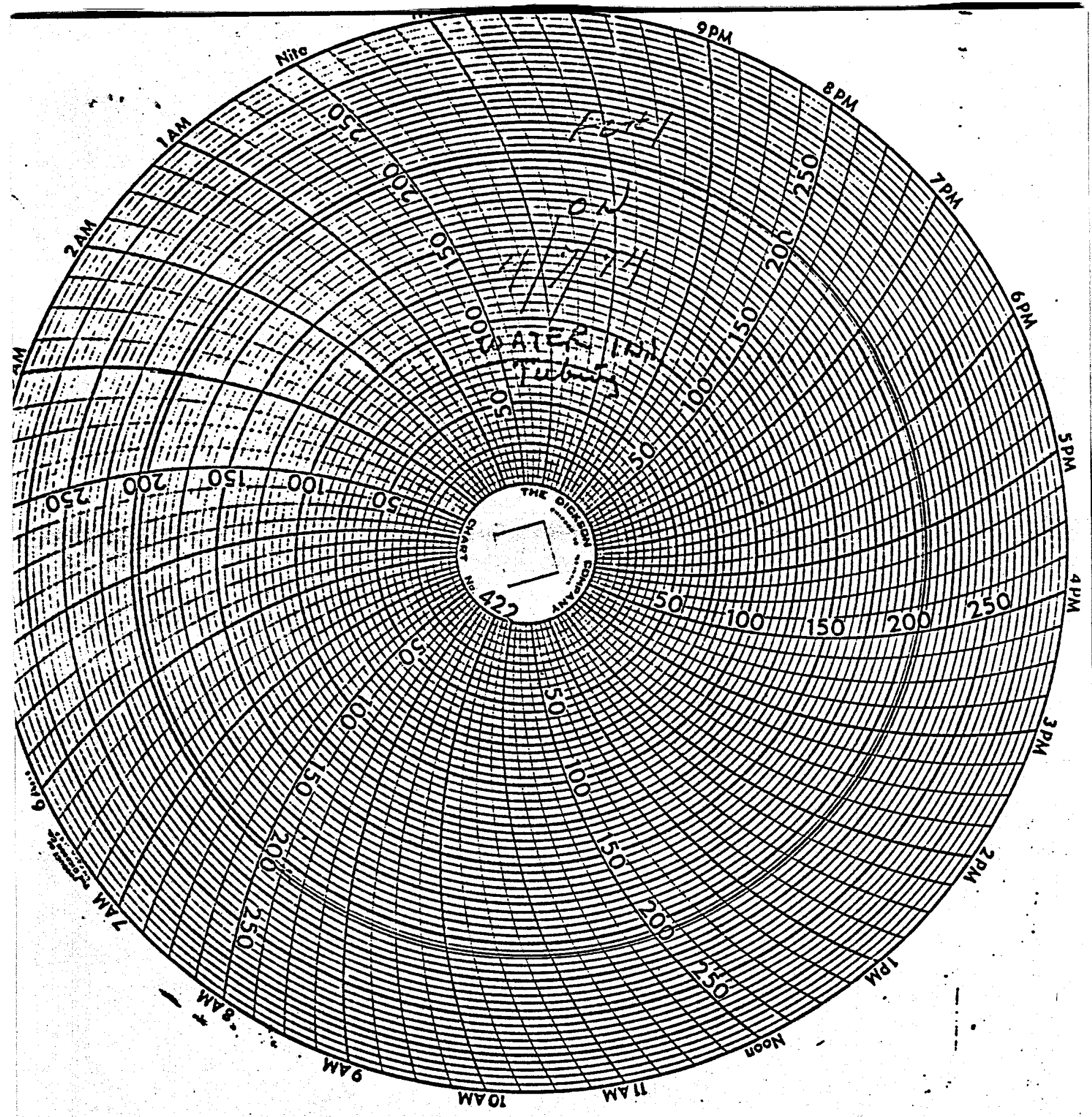




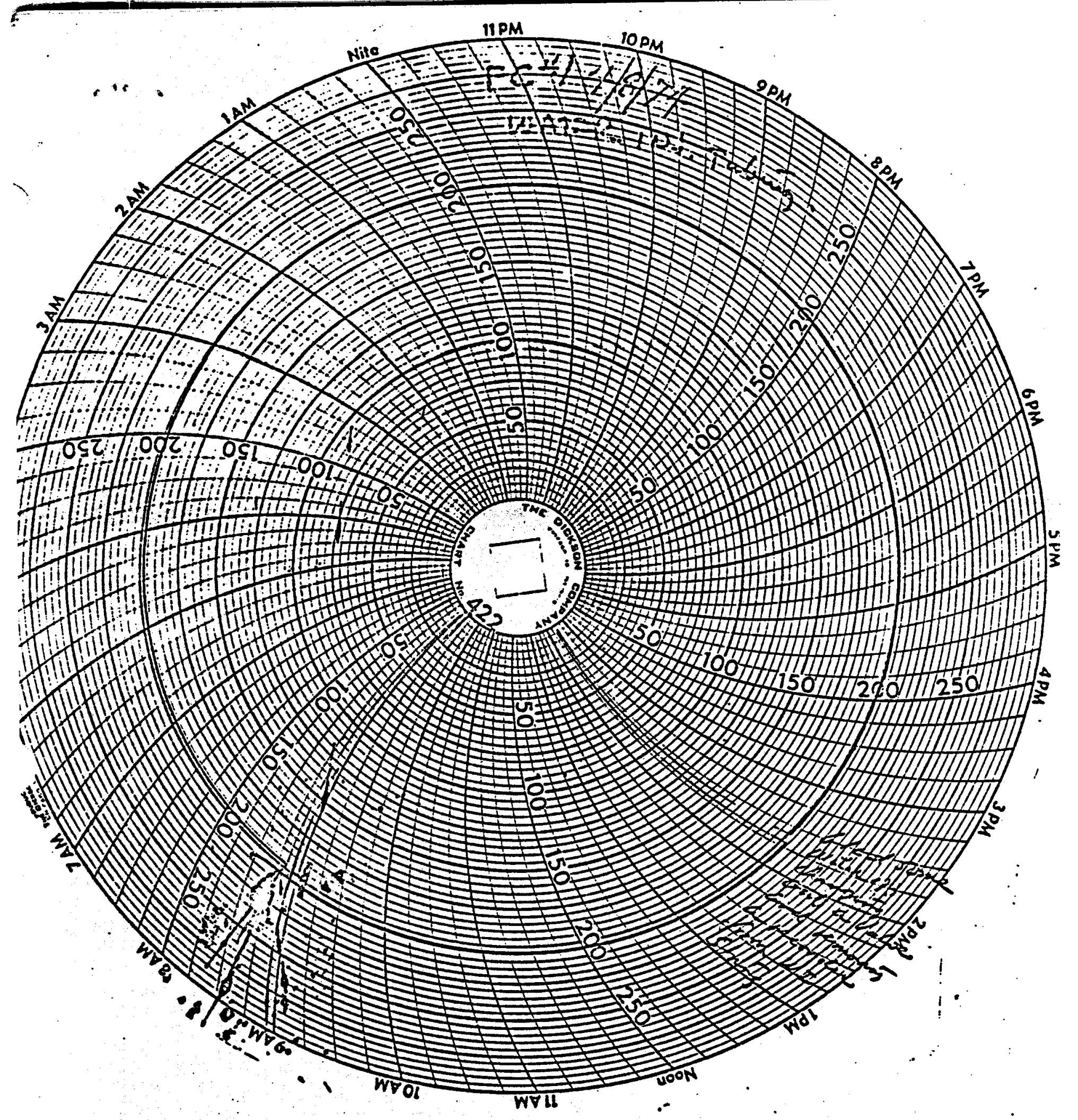




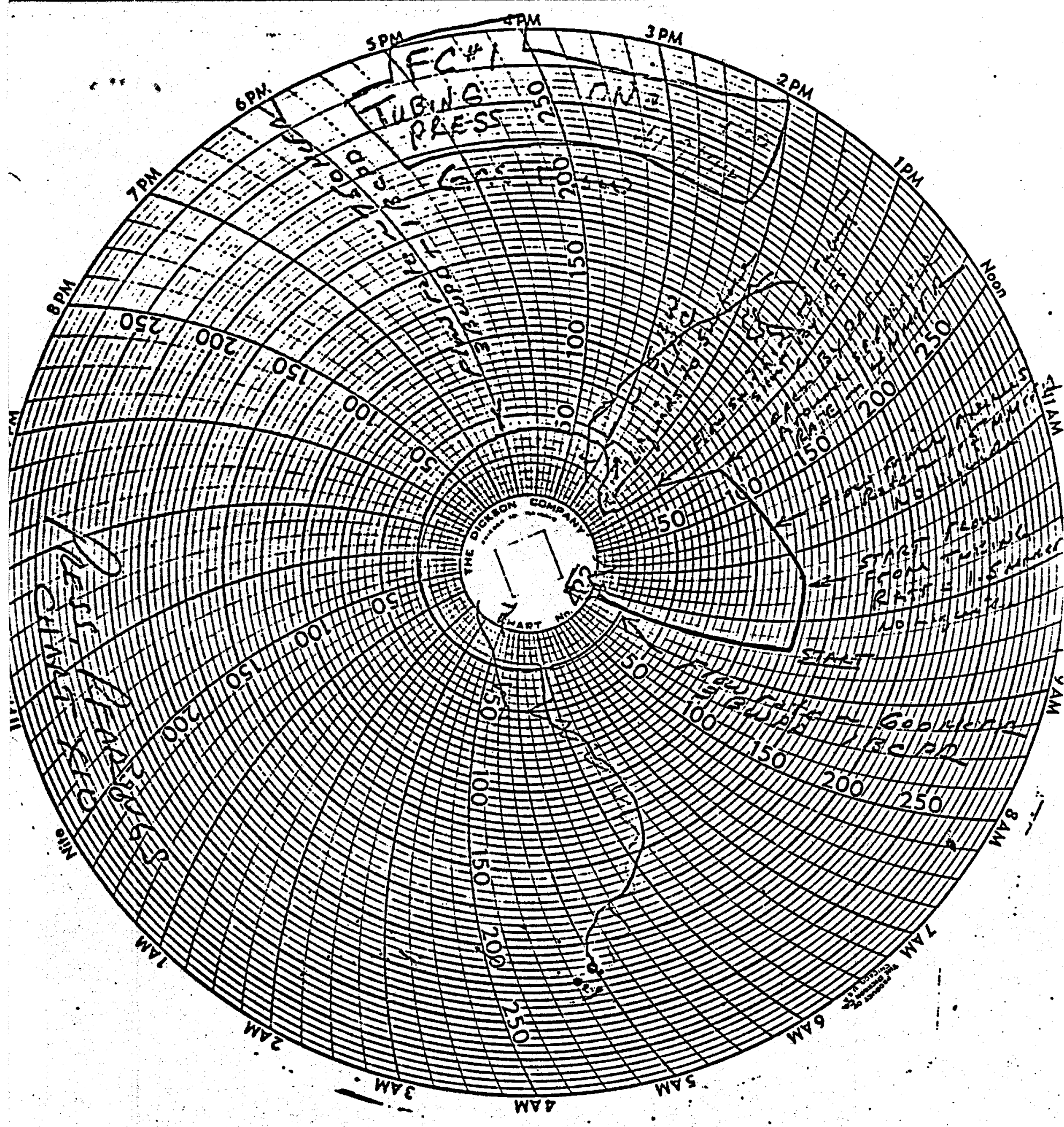




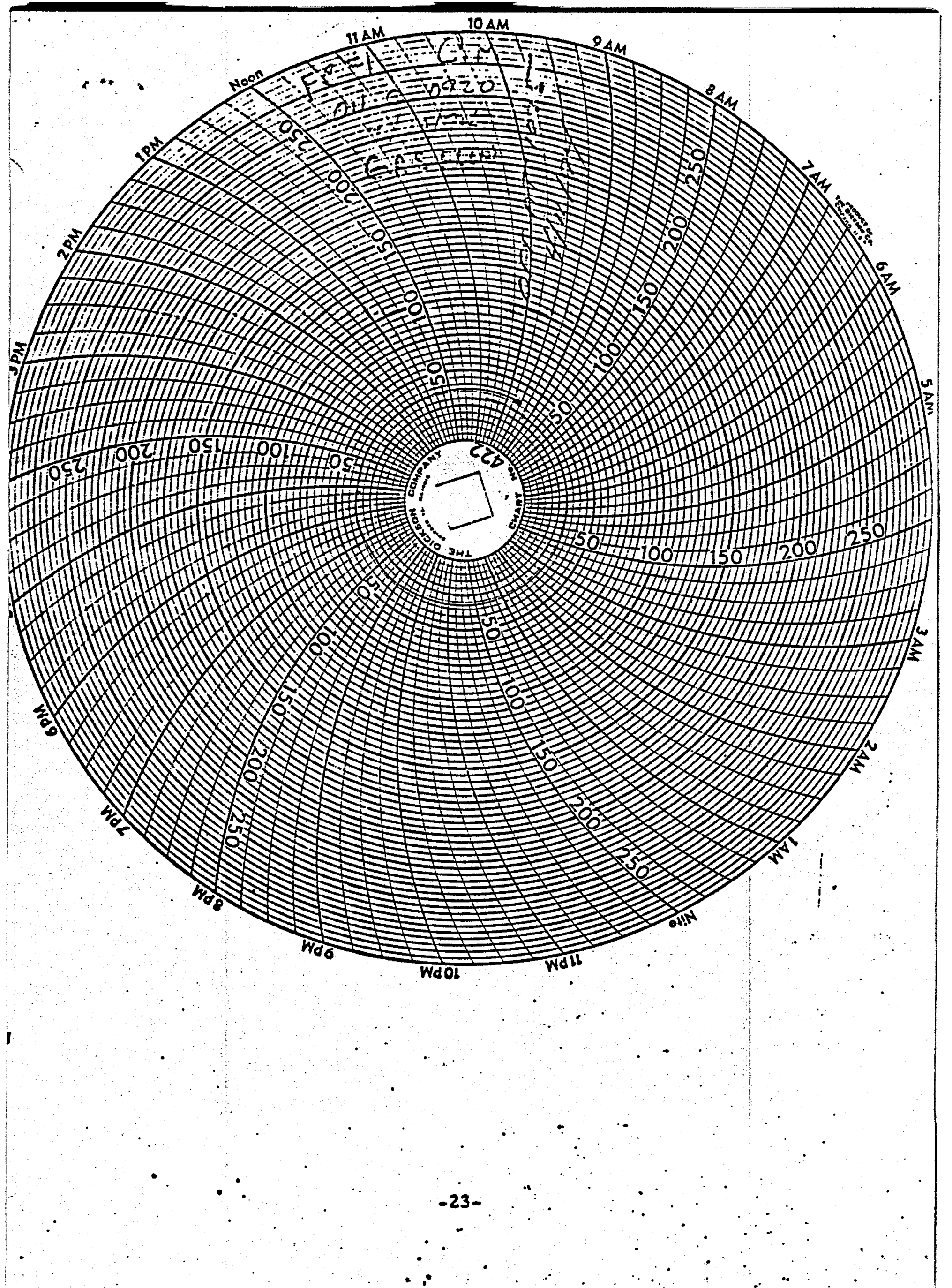


'Appendix C

Tabie I

EIC ON SITE GAS TRITIUM ANALYSES

(EPA Burner Unless otherwise noted)

1974

DATE TIME PCi/1 gas

\begin{tabular}{|c|c|c|}
\hline \multirow[t]{4}{*}{9 April } & 0845 & ND* \\
\hline & 0854 & $N D * *$ \\
\hline & 1100 & ND \\
\hline & 1145 & ND** \\
\hline \multirow{10}{*}{$4+4+8$} & 1145 & ND** \\
\hline & 1245 & ND \\
\hline & 1310 & ND \\
\hline & 1315 & ND \\
\hline & 1320 & ND \\
\hline & 1510 & ND** \\
\hline & 1800 & ND** \\
\hline & 1812 & ND \\
\hline & 2236 & ND** \\
\hline & 2244 & ND \\
\hline \multirow[t]{4}{*}{10 April } & 0606 & ND \\
\hline & 0918 & ND \\
\hline & 1116 & ND \\
\hline & 1725 & ND \\
\hline \multirow[t]{2}{*}{11 April } & 0820 & ND \\
\hline & 1024 & ND \\
\hline
\end{tabular}

\section{REMARKS}

Tubing before flow

Tubing before flow without molysieve

Tubing without molysieve

Tubing before separator without molysieve

Annulus before separator

Annulus without molysieve

Tubing trithout molysieve

Tubing trithout molysieve

Annulus without molysieve

After separator

Tubing wjthout molysieve

Tubing without molysieve

Tubing without molysieve

Tubing without molysieve

Tubing wi thout molysieve

Tubing wi thout molysieve

Tubing wi thout molysieve

Tubing without molysieve

Tubing without molysieve

Tubing without molysieve

* ND (not detectable) means less than $4 \mathrm{pCi} / 1$ of gas

** Oxidizer -....-- 


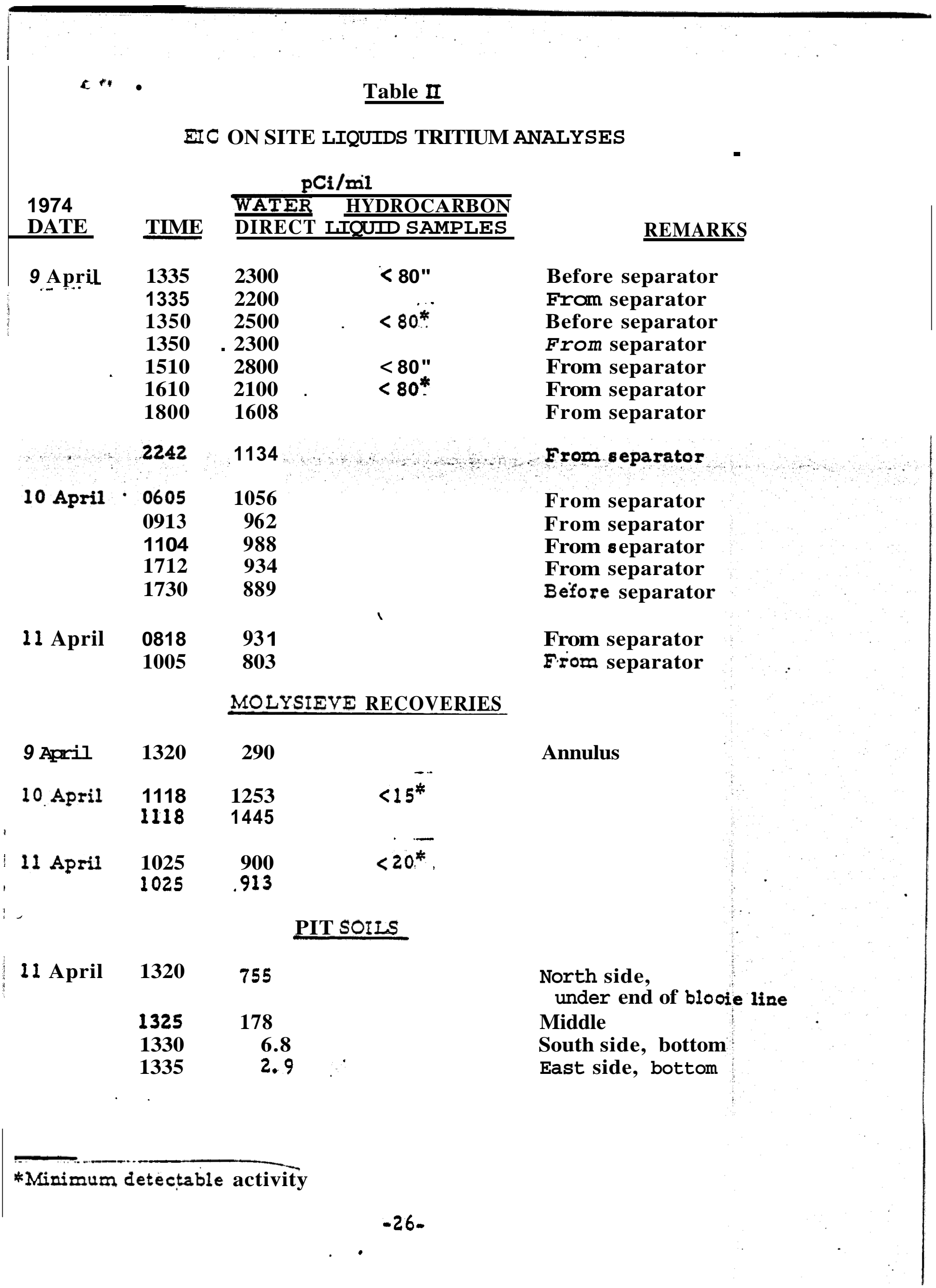




\section{- Table II}

\section{COMPARISON OF LLL AND NERC-LV}

GAS TRITIUM ANALYSES

\begin{tabular}{|c|c|c|c|c|c|c|}
\hline TIME & ${ }_{L L I}^{222} \mathrm{Rn}$ & NER/C-L.V & $\begin{array}{l}{ }^{3} \mathrm{~F} \mathrm{p} \\
\text { Dried }\end{array}$ & $\begin{array}{l}i / 1 \\
\text { Gas }\end{array}$ & $\begin{array}{l}\mathrm{oci} / \mathrm{mol}^{2} \\
\text { Lequid }\end{array}$ & 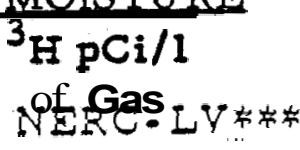 \\
\hline 1110 & & $76 \pm 7.1$ & & $-1.1 \pm 0.34=$ & & co. 011 \\
\hline 0900 & $58 \pm 2$ & $48 \pm 7.1$ & $0.03 \pm 0.04 \%$ & $c 0.32$ & & $<0.021$ \\
\hline 1143 & & $.87 \pm 3.1$ & & $1.0 \pm 0.34$ & & $0.71 \pm 0.04$ \\
\hline 1800 & $120+3$ & $95 \pm 9.6$ & $0 \leq 4 \div$ & $<0.30$ & & $0.2 \leq 0.012$ \\
\hline 1110 & $120 \pm 2$ & $110 \pm 9.5$ & $0.1 \pm 0.04$ & $<0.30$ & $880 \pm 10$ & $\ldots$ \\
\hline 1720 & $120+2$ & $110 \pm 9.3$ & $0 \pm 4 *$ & $<0.30$ & & - \\
\hline 0818 & $130 \pm 2$ & & $0.03 \pm 0.03$ & & $720 \pm 10$ & $\ldots$ \\
\hline 1010 & $120 \pm 6$ & $120 \pm 9.3$ & $0 \pm 4 * *$ & $<0.30$ & $680 \pm 10$ & \\
\hline
\end{tabular}

$\square$ low level proportional counting system L burner system tes not recoverable or not'recovered quantitatively sitive values are lower limits 